Cipango Cahiers d'études japonaises

$20 \mid 2013$

Nouveaux regards sur les arts de la scène japonais I

\title{
La dérive est la nourriture de notre vie (1976)
}

\section{Yutaka Higashi}

Traducteur : Toshio Takemoto

\section{OpenEdition}

Journals

\section{Édition électronique}

URL : https://journals.openedition.org/cipango/1986

DOI : $10.4000 /$ cipango.1986

ISSN : 2260-7706

Éditeur

INALCO

Édition imprimée

Date de publication : 30 octobre 2013

ISSN : 1164-5857

\section{Référence électronique}

Yutaka Higashi, «La dérive est la nourriture de notre vie (1976) », Cipango [En ligne], 20 | 2013, mis en ligne le 17 avril 2015, consulté le 30 juin 2021. URL : http://journals.openedition.org/cipango/1986 ; DOI : https://doi.org/10.4000/cipango.1986

Ce document a été généré automatiquement le 30 juin 2021.

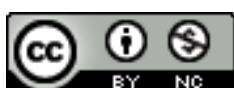

Cipango est mis à disposition selon les termes de la Licence Creative Commons Attribution - Pas d'Utilisation Commerciale 4.0 International. 


\title{
La dérive est la nourriture de notre vie (1976)
}

\author{
Yutaka Higashi \\ Traduction : Toshio Takemoto
}

1 Higashi Yutaka 東由多加, «Hōrō wa oretachi no inochi no kate» 放浪は俺たちの命の 糧 in Higashi Yutaka ga nokoshita kotoba 東由多加が遺した言葉 (Mots laissés par Higashi Yutaka), Tōkyō, Jiritsu shobō 而立書房, 2002, p. 46-47.

2 Nous sommes tous en voyage. Même lorsque nous écoutons une chanson de trois minutes, nous sommes capables de voyager. Il arrive qu'un livre ou un film, agissant certainement comme carte pour l'âme, nous fasse vagabonder.

Disons-le : aimer, c'est une dérive où justement l'être humain ne peut fuir.

4 Moi, je ne suis pas très doué pour voyager dans le monde réel. Lorsque, pour la première fois de ma vie, j'ai décidé de voyager seul, je suis allé à Kyōto, j'ai fait la tournée des cafés et des cinémas, et ce n'est que quand j'ai acheté une carte postale à la gare, sur le chemin du retour, que je me suis enfin senti soulagé. Mais lorsque je téléphone à mon amie, il me semble partir pour un grand voyage en mer. Durant notre conversation, j'ai le sentiment d'errer sans point d'ancrage sur «la sente étroite de l'amour $~$. Le voyage n'est-il pas un rêve mélancolique ? Rêver de lointain avec extase et angoisse, telle serait la passion du voyage. Le voyage n'existe pas en lui-même. Il peut être dans la vie quotidienne, dans un appartement ou dans un café, dans le métro ou dans un bar, ou bien au sein de l'entreprise où l'on travaille. Moi, je préfère dire: «je veux aller à côté » que «je veux aller loin ». En vérité, ne désirons-nous pas flâner dans un paysage familier plutôt que dans une ville inconnue?

5 Sait-on s'il fait beau en Espagne en ce moment ? Peu importe ! Dans un verre de whisky, il nous arrive d'entrevoir le ciel azur de la Grèce. Pourtant la force de l'imagination n'est pas le voyage. Le sentiment violent du voyage n'est ni dans la fantaisie ni dans l'illusion, mais dans le rapport à la fois lointain et proche avec la réalité.

6 J'ai rencontré Akita Meidai au bout de notre dérive. Nous vivons sous le même toit à présent, tels des soldats blessés et épuisés. 
7 Akita va sans doute partir bientôt en Inde. Moi, tout en buvant à Tōkyō, j'imagine cet homme sur sa moto au bord de l'Indus, et je voyage alors dans mon cœur. Si je continuais d'aspirer vers cet homme qu'est Akita Meidai, il serait bel et bien pour moi une carte pour vivre. Mais pas le passage de la révolution à la vie quotidienne. Il est une carte pour le labyrinthe où l'homme erre afin de vivre.

\section{NOTES}

1. Référence à sa Sente étroite du Bout-du-Monde (Oku no hosomichi 奥の細道) de MATSUo Bashō 松尾 芭蕉 (1644-1694), carnet de voyage relatant le périple de l'auteur. 